Article

\title{
Cold Storage and Biocontrol Agents to Extend the Storage Period of 'BRS Isis' Seedless Table Grapes
}

\author{
Ronan Carlos Colombo ${ }^{1}$, Deived Uilian Carvalho ${ }^{1}$, Maria Aparecida da Cruz ${ }^{1}$, \\ Ciro Hideki Sumida ${ }^{1}$, Saeed Ahmed ${ }^{1}$, Paulo Augusto Bassoli ${ }^{1}$, Reginaldo Teodoro de Souza ${ }^{2}$ \\ and Sergio Ruffo Roberto ${ }^{1, *}$ (1) \\ 1 Agricultural Research Center, Londrina State University, Celso Garcia Cid Road, km 380, P.O. Box 10.011, \\ Londrina ZIP 86057-970, PR, Brazil; ronancolombo@yahoo.com.br (R.C.C.); deived10@gmail.com (D.U.C.); \\ mary_ac18@hotmail.com (M.A.d.C.); cirosumida@uel.br (C.H.S.); saeeddikhan@gmail.com (S.A.); \\ pauloaugustobassoli@gmail.com (P.A.B.) \\ 2 Embrapa Grape and Wine, 515 Livramento Drive, Bento Gonçalves ZIP 95700-000, RS, Brazil; \\ reginaldo.souza@embrapa.br \\ * Correspondence: sroberto@uel.br; Tel.: +55-043-3371-4774
}

Received: 13 July 2018; Accepted: 14 August 2018; Published: 15 August 2018

\begin{abstract}
BRS Isis' is a novel hybrid seedless table grape with large reddish bunches. This cultivar is cultivated in tropical and subtropical areas and has potential to be exported overseas; however, under these growth conditions, grapes can be severely damaged by gray mold (Botrytis cinerea), the main postharvest disease of table grapes. Thus, this study aimed to evaluate different pre- and postharvest strategies to extend the storage period of 'BRS Isis' seedless table grapes. The treatments consisted of grapes packed into carton boxes under cold storage $\left(1^{\circ} \mathrm{C}\right.$ and high relative humidity), pre- and /or postharvest treatment with potassium bicarbonate or a biological control agent (Bacillus subtilis), all with Botrytis inoculation. Additionally, two controls, with and without Botrytis inoculation, were also evaluated. The experimental design was completely randomized with eight treatments and three replications, and each plot consisted of four bunches. After a 50-day cold storage period, the carton boxes were kept for five days at room temperature $\left(22^{\circ} \mathrm{C}\right)$. Gray mold incidence and water loss, as well as soluble solids (SS), pH, titratable acidity (TA), SS/TA ratio, and color attributes were evaluated during both periods. Cold storage effectively reduced gray mold in 'BRS Isis' seedless grape for a period of 50 days, even when grapes were inoculated; however, no difference among treatments was observed. Higher water loss was observed in both non-treated control treatments.
\end{abstract}

Keywords: Bacillus subtilis; Botrytis cinerea; potassium bicarbonate; salt strategy; seedless grapes

\section{Introduction}

In a market where consumers expect products of high quality throughout the year, maintenance and improvement of fruit quality at postharvest are becoming increasingly important [1]. Among fruits, grapes contain a wide variety of compounds that improve health, such as phenolic compounds that neutralize free radicals [2-4].

'BRS Isis', a novel hybrid seedless table grape cultivar released in 2013, has large red berries and a crunchy texture. This grape was obtained by crossing CNPUV 681-29 [Arkansas $1976 \times$ CNPUV 147-3 ('White Niagara' $\times$ 'Venus')] $\times$ 'BRS Linda'. It is recommended for cultivation in tropical and subtropical areas, with excellent horticultural performance, high bud fecundity and tolerance to downy mildew (Plasmopara viticola), the most important disease affecting grapevines in subtropical humid conditions $[5,6]$. 
'BRS Isis' seedless grapes have the potential to supply national and international fresh fruit markets throughout the year. Low temperature storage is one of the most commonly used methods to prolong postharvest quality and extend the shelf-life of a broad range of horticultural commodities.

However, its use is sometimes limited, depending on the fruit's susceptibility to chilling injury and/or fungal decay during storage, and on how the quality of the fruit is affected by its maturation stage at harvest $[1,7]$. Grapes destined for long-distance transport and export must be kept under low temperatures $\left(\sim 1^{\circ} \mathrm{C}\right)$ and high relative humidity to preserve their main characteristics and keep them free of diseases and injuries. However, studies on the postharvest behavior of 'BRS Isis' is not known.

In subtropical areas, grape harvest can occur during high favorable conditions for the development of postharvest fungal diseases, which can limit the long-distance transportation of fresh grapes [8-10]. Among fungal diseases, gray mold, caused by Botrytis cinerea Pers. Fr., is considered the main cause of postharvest decay of table grapes, resulting in severe losses during cold storage transport overseas [11,12].

The traditional control of gray mold infection consists of the field application of synthetic fungicides during the grapevine growing cycle, and several groups of synthetic fungicides that are able to control gray mold infections are available $[13,14]$. However, fungicide use is strictly regulated by national and international regulations, and currently, very few active ingredients are allowed against postharvest diseases. In addition, preharvest fungicide applications are not always effective in preventing and controlling gray mold infections during long-term storage. Their efficacy is strictly related to the timing of application [15], and for safety reasons, their application is no longer allowed in many countries [10].

The reduction in chemical efficacy due to the development of pathogen resistant strains has also been reported, leading grape growers to evaluate safer alternatives for controlling postharvest diseases within the context of sustainable agriculture. These alternatives include natural compounds of animal and plant origin, organic and inorganic salts, antagonistic microorganisms, and physical methods; these all represent approaches that have been recently evaluated to ensure optimal fruit quality [16-19].

Some strategies to inhibit fungal diseases in table grapes during the postharvest period have been recommended. For example, treatments with salt solutions such as potassium bicarbonate have been recommended for inhibiting gray mold in 'Italia' and 'Benitaka' table grapes [18,19], as well as cold storage combined with sulfur dioxide $\left(\mathrm{SO}_{2}\right)[10,20-23]$.

Resistance inducers have also been used to control postharvest fungal diseases in other crops, and they have shown promising results in banana [24,25], strawberry [26,27], melon [28], and lemon [29]. More recently, biological products, such as Bacillus subtilis and Trichoderma sp. have been employed as biological control agents [30-32].

Therefore, the objective of this study was to evaluate the quality of 'BRS Isis' seedless table grapes under cold storage and treated with potassium bicarbonate or B. subtilis as a microbiological fungicide agent.

\section{Materials and Methods}

\subsection{Experimental Location}

'BRS Isis' seedless table grape bunches were harvested in December 2016 in a commercial vineyard located at Marialva, State of Parana (PR) (South Brazil) $\left(23^{\circ} 29^{\prime} \mathrm{S}, 51^{\circ} 47^{\prime} \mathrm{W}\right.$, altitude $570 \mathrm{~m}$ ). According to the Köppen classification, the local climate is $\mathrm{Cfa}$ (subtropical humid). The fungicide program used in the experimental area to control gray mold consisted of two applications of iprodione, at veraison and at 14 days after the first application. During this season (summer), the weather condition was humid (summer is considered part of the rainy season), which increased the chance of infection. The vines were grafted onto 'IAC 766 Campinas' and trained on an overhead trellis with $18 \%$ plastic mash screen. 


\subsection{Fungal Identification and Suspension}

Botrytis cinerea used in this study was isolated from infected grapes from the same vineyard; these grapes showed typical gray mold symptoms. The fungus was purified and identified morphologically and molecularly [18]. The single-race isolates were maintained on PDA (potato dextrose agar) slants and stored at $4{ }^{\circ} \mathrm{C}$ for further use. The B. cinerea isolates were cultured on PDA Petri plates for 7 days at $23 \pm 1{ }^{\circ} \mathrm{C}$. After 7 days of culture, $5 \mathrm{~mL}$ of sterile water containing $0.05 \%$ $(v / v)$ Tween 80, was added to the Petri plate and mycelia were scratched off and kept under near ultra violet radiation at a $12 \mathrm{~h} / 12 \mathrm{~h}$ light-dark photoperiod to induce sporulation. Spores were collected and counted with a hemacytometer (Bright-Line ${ }^{\circledR}$, Cambridge Instruments Inc., Cambridge, UK). Conidial

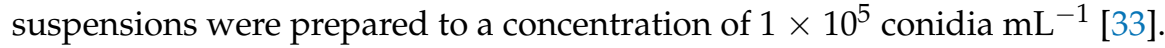

\subsection{Treatments and Experimental Design}

One week before harvest, grape bunches were sprayed with the preharvest treatments (see Table 1): potassium bicarbonate $\left(1 \%(\mathrm{~m} / \mathrm{v}),\left(\mathrm{KHCO}_{3}, 99.7 \%\right.\right.$ purity, LabSynth, Brazil $\left.)\right)$ at a rate of $800 \mathrm{~L}$ of solution per ha; Serenade ${ }^{\circledR}$ (Bayer, Brazil), a biological fungicide containing Bacillus subtilis, applied at a rate of $3 \mathrm{~L} \mathrm{ha}^{-1}$ of commercial product diluted in $800 \mathrm{~L}$ of water; and a control, with no application. The experimental design was completely randomized with eight treatments and three replications.

One week after applications, grape bunches were harvested and subjected to postharvest treatments, as shown in Table 1.

Table 1. Treatments applied at pre- and postharvest on 'BRS Isis' seedless table grapes.

\begin{tabular}{|c|c|c|}
\hline Treatment & Product & Application Time \\
\hline Control & Distilled water & Postharvest \\
\hline Control + Botrytis & Distilled water & Postharvest \\
\hline PreH PB + Botrytis & Potassium bicarbonate $(\mathrm{PB})$ at $1 \%(m / v)$ & Preharvest (PreH) \\
\hline PreH/PostH PB + Botrytis & Potassium bicarbonate $(\mathrm{PB})$ at $1 \%(\mathrm{~m} / \mathrm{v})$ & Pre- and postharvest (PreH/PostH) \\
\hline PostH PB + Botrytis & Potassium bicarbonate $(\mathrm{PB})$ at $1 \%(\mathrm{~m} / \mathrm{v})$ & Postharvest (PostH) \\
\hline PreH Se + Botrytis & Serenade ${ }^{\circledR}(\mathrm{Se}) 3 \mathrm{~L} \mathrm{ha}^{-1}$ & Preharvest (PreH) \\
\hline PreH/PostH Se + Botrytis & Serenade $^{\circledR}(\mathrm{Se}) 3 \mathrm{~L} \mathrm{ha}^{-1}$ & Pre- and postharvest (PreH/PostH) \\
\hline PostH Se + Botrytis & Serenade $^{\circledR}(\mathrm{Se}) 3 \mathrm{~L} \mathrm{ha}^{-1}$ & Postharvest (PostH) \\
\hline
\end{tabular}

Botrytis inoculation was performed by spraying a conidial suspension $\left(1 \times 10^{5}\right.$ conidia $\left.\mathrm{mL}^{-1}\right)$. Then, the bunches were left to dry at room temperature for $1 \mathrm{~h}$, and placed in carton boxes measuring $13 \times 30 \times 40 \mathrm{~cm}$ and lined with perforated plastic. The boxes were stored in a cold chamber for 50 days at $1{ }^{\circ} \mathrm{C}$ and high $\mathrm{RH}$, followed by a 5 -day period of shelf-life at $22 \pm 2{ }^{\circ} \mathrm{C}$. The completely randomized design consisted of three replications per treatment and four bunches per replication.

\subsection{Analysis Performed}

At the end of the 50-day cold storage and the 5-day shelf-life periods, the following variables were evaluated for grape quality measurements:

\subsubsection{Gray Mold Incidence}

The incidence of gray mold on bunches caused by B. cinerea was measured according to the following formula: disease incidence $(\%)=($ number of decayed berries $/$ total number of berries $) \times 100$ [18].

\subsubsection{Physicochemical Analysis}

Water loss (\%) was calculated as a percentage of mass lost by the bunch from the beginning to the end of the cold storage/shelf-life period. The difference as a percentage from the original mass was calculated as: $($ water loss $\%=$ [(initial mass - mass at examined date $) /$ initial mass $] \times 100)$ [34] . 
Berry color was analyzed using a colorimeter (Konica Minolta ${ }^{\circledR}$ CR-10, Tokyo, Japan) to obtain the following variables from the equatorial portion of 10 berries per plot: luminosity $\left(L^{*}\right)$, chroma $\left(C^{*}\right)$ and hue angle $\left(h^{\circ}\right)$ and, subsequently the color index for red grapes (CIRG) was determined using the formula: $\mathrm{CIRG}=\left(180-h^{\circ}\right) /\left(L^{*}+C^{*}\right)[35]$.

The chemical characteristics of bunches were assessed by determining the soluble solids (SS, ${ }^{\circ}$ Brix), titratable acidity (TA, \% of tartaric acid), and SS/TA ratio [36]. To perform the chemical analysis, 10 berries were collected in each plot.

\subsection{Statistical Analysis}

The data recorded were subjected to analysis of variance (ANOVA) and the means were compared by Scott-Knott's test at $p \leq 0.05$.

\section{Results}

The application of potassium bicarbonate and Serenade ${ }^{\circledR}$ one week before harvest did not affect the mass and chemical properties of grape bunches at harvest (Table 2). Cold storage was efficient at reducing gray mold of 'BRS Isis' seedless grapes for a period of 50 days, even when grapes were inoculated; however, we observed no differences among treatments (Table 3). Figure 1 shows 'BRS Isis' seedless table grape bunches with typical symptoms of gray mold infection.

Table 2. Bunch mass (BM), soluble solids content (SS), $\mathrm{pH}$, total acidity (TA), and maturation index (MI - SS/TA) ratio recorded in 'BRS Isis' seedless table grapes subjected to different preharvest treatments.

\begin{tabular}{cccccc}
\hline Treatments & BM (kg) & SS $\left({ }^{\circ}\right.$ Brix) & pH & TA (\%) & MI (SS/TA) \\
\hline Control & $0.54^{\mathrm{ns} \mathrm{z}}$ & $14.37^{\mathrm{ns}}$ & $4.34^{\mathrm{ns}}$ & $0.61^{\mathrm{ns}}$ & $23.49^{\mathrm{ns}}$ \\
Potassium bicarbonate 1\% & 0.50 & 14.69 & 4.34 & 0.60 & 24.75 \\
Serenade $^{\circledR}$ 3 L ha ${ }^{-1}$ & 0.55 & 14.46 & 4.34 & 0.60 & 24.08 \\
\hline $\mathrm{CV}(\%)$ & 8.52 & 2.02 & 0.72 & 6.39 & 6.01 \\
\hline \multicolumn{5}{c}{${ }^{\mathrm{z}}$ ns: differences not significant. CV: coefficient of variation. }
\end{tabular}

Table 3. Gray mold incidence and water loss in 'BRS Isis' seedless table grapes subjected to preharvest $(\mathrm{PreH})$, pre- and postharvest (PreH/PostH), and postharvest (PostH) treatments at 50 days after cold storage (50-ACS) and at five days after shelf-life (5-ASL).

\begin{tabular}{ccccc}
\hline \multirow{2}{*}{ Treatments $^{\mathbf{z}}$} & \multicolumn{2}{c}{ Gray Mold (\%) } & \multicolumn{2}{c}{ Water Loss (\%) } \\
\cline { 2 - 5 } & 50-ACS & 5-ASL & 50-ACS & 5-ASL \\
\hline Control & $2.13^{\mathrm{ns} y}$ & $1.28 \mathrm{~b}$ & $7.64 \mathrm{a}$ & $7.06^{\mathrm{ns}}$ \\
Control + Botrytis & 5.00 & $6.00 \mathrm{a}$ & $8.58 \mathrm{a}$ & 6.98 \\
PreH PB + Botrytis & 5.57 & $5.40 \mathrm{a}$ & $4.96 \mathrm{~b}$ & 7.16 \\
PreH/PostH PB + Botrytis & 10.11 & $9.00 \mathrm{a}$ & $5.27 \mathrm{~b}$ & 8.15 \\
PostH PB + Botrytis & 7.60 & $7.79 \mathrm{a}$ & $5.28 \mathrm{~b}$ & 8.55 \\
PreH Se + Botrytis & 4.93 & $5.36 \mathrm{a}$ & $5.00 \mathrm{~b}$ & 7.07 \\
PreH/PostH Se + Botrytis & 5.00 & $5.11 \mathrm{a}$ & $5.49 \mathrm{~b}$ & 7.60 \\
PostH Se + Botrytis & 6.11 & $6.59 \mathrm{a}$ & $4.98 \mathrm{~b}$ & 7.90 \\
\hline CV (\%) & 25.68 & 18.05 & 17.27 & 11.10 \\
\hline
\end{tabular}

z Treatments: potassium bicarbonate $1 \%(\mathrm{~PB})$ and Serenade ${ }^{\circledR} 3 \mathrm{~L} \mathrm{ha}^{-1}(\mathrm{Se}) .{ }^{\mathrm{y}}$ Means in a column followed by different letters are statistically different according to Scott-Knott's test $(p \leq 0.05)$. ns: differences not significant. CV: coefficient of variation. ACS: days after cold storage; ASL: days after shelf-life.

At the end of the five-day shelf-life period, the gray mold incidence in control (non-inoculated) bunches was lower than at the end of the 50-day cold storage period, and lower than the levels observed in the inoculated treatments (Table 3). The temperature of the shelf-life period was close to $22^{\circ} \mathrm{C}$, which is unfavorable to gray mold development, which explains why we did not observe any 
increase in berry decay and gray mold incidence. In addition, it is also possible that the treatment broke down the balance of microorganism communities of grape, and some gray mold antagonists were destroyed.

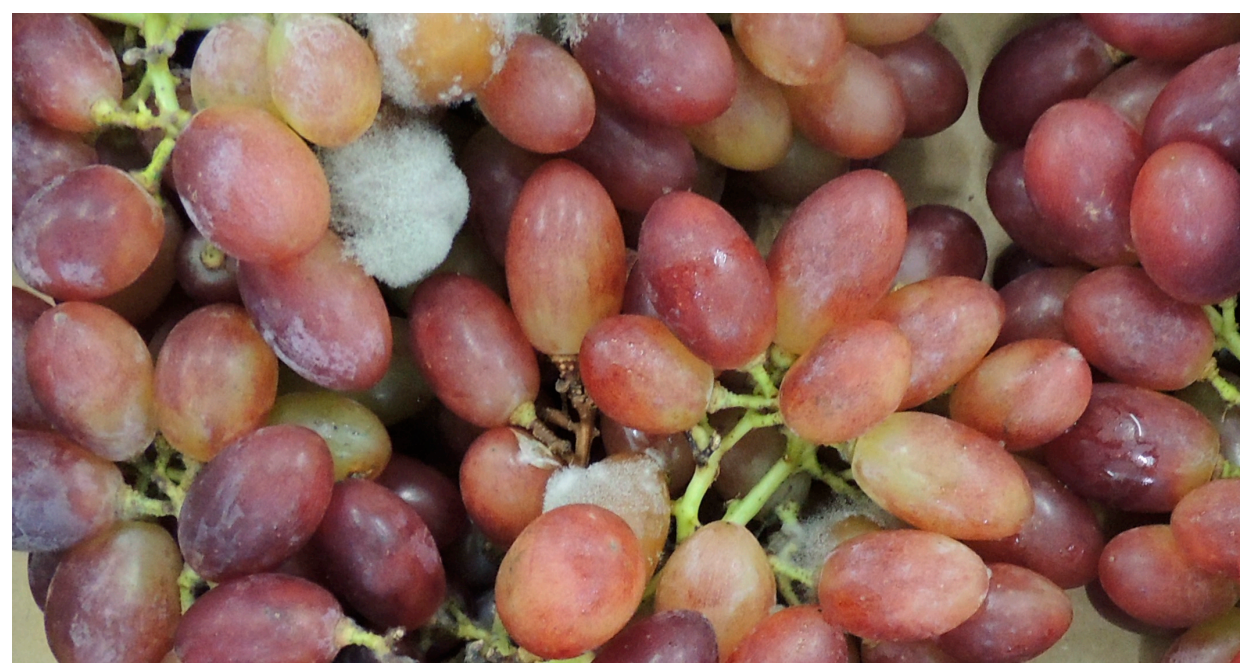

Figure 1. 'BRS Isis' seedless table grape bunches presenting typical gray mold (Botrytis cinerea) symptoms.

After storage, the bunches treated with potassium bicarbonate and Serenade ${ }^{\circledR}$ presented lower water losses than those of control bunches. In treated bunches, the water loss ranged from 4.0 to $5.5 \%$, whereas in both control treatments, the bunch mass was reduced by $8 \%$. However, this water loss recorded at the end of cold storage was not observed during the shelf-life period, where water losses were similar for all treatments, with means ranging from 7 to $8.5 \%$ (Table 3). After the 50-day cold storage period, significant differences in soluble solids content were observed among the treatments (Table 4). On the other hand, there were no differences in berry color attributes observed after 50 days of cold storage (Table 5).

Table 4. Soluble solids content (SS), $\mathrm{pH}$, titratable acidity (TA), and SS/TA ratio of 'BRS Isis' seedless table grapes subjected to different preharvest ( $\mathrm{PreH})$, pre- and postharvest (PreH/PostH), and postharvest (PostH) treatments, at 50 days after cold storage (50-ACS) and at five days after shelf-life (5-ASL).

\begin{tabular}{|c|c|c|c|c|c|c|c|c|}
\hline \multirow{2}{*}{ Treatments $^{z}$} & \multicolumn{2}{|c|}{ SS $\left({ }^{\circ}\right.$ Brix $)$} & \multicolumn{2}{|c|}{$\mathrm{pH}$} & \multicolumn{2}{|c|}{ TA (\%) } & \multicolumn{2}{|c|}{ SS/TA } \\
\hline & 50-ACS & 5-ASL & 50-ACS & 5-ASL & 50-ACS & 5-ASL & 50-ACS & 5-ASL \\
\hline Control & $14.30 c^{y}$ & $14.90 \mathrm{~b}$ & $4.54^{\mathrm{ns}}$ & $4.50 \mathrm{~b}$ & $0.62^{\mathrm{ns}}$ & $0.64^{\mathrm{ns}}$ & $23.34^{\mathrm{ns}}$ & $23.38^{\mathrm{ns}}$ \\
\hline Control + Botrytis & $14.10 \mathrm{c}$ & $14.03 \mathrm{~b}$ & 4.49 & $4.47 \mathrm{~b}$ & 0.64 & 0.68 & 22.22 & 20.66 \\
\hline PreH PB + Botrytis & $16.27 \mathrm{a}$ & $16.77 \mathrm{a}$ & 4.50 & $4.73 \mathrm{a}$ & 0.66 & 0.68 & 24.74 & 24.84 \\
\hline PreH/PostH PB + Botrytis & $15.83 \mathrm{a}$ & $16.77 \mathrm{a}$ & 4.61 & $4.29 \mathrm{c}$ & 0.64 & 0.65 & 24.93 & 25.74 \\
\hline PostH PB + Botrytis & $14.10 \mathrm{c}$ & $15.17 \mathrm{~b}$ & 4.51 & $4.46 \mathrm{~b}$ & 0.64 & 0.68 & 22.29 & 22.47 \\
\hline PreH Se + Botrytis & $15.10 \mathrm{~b}$ & $14.77 \mathrm{~b}$ & 4.48 & $4.30 \mathrm{c}$ & 0.59 & 0.69 & 25.75 & 21.75 \\
\hline PreH/PostH Se + Botrytis & $14.73 \mathrm{~b}$ & $15.13 \mathrm{~b}$ & 4.48 & $4.31 \mathrm{c}$ & 0.62 & 0.65 & 23.89 & 23.33 \\
\hline PostH Se + Botrytis & $14.13 \mathrm{c}$ & $14.43 \mathrm{~b}$ & 4.54 & $4.48 \mathrm{~b}$ & 0.61 & 0.71 & 23.15 & 20.42 \\
\hline CV $(\%)$ & 2.70 & 5.05 & 1.14 & 2.70 & 6.47 & 6.01 & 8.34 & 9.20 \\
\hline
\end{tabular}

${ }^{\mathrm{z}}$ Treatments: potassium bicarbonate $1 \%(\mathrm{~PB})$ and Serenade ${ }^{\circledR} 3 \mathrm{~L} \mathrm{ha}^{-1}(\mathrm{Se}) .{ }^{\mathrm{y}}$ Means in a column followed by different letters are statistically different according to Scott-Knott's test $(p \leq 0.05)$. ns: differences not significant. CV: coefficient of variation. ACS: days after cold storage; ASL: days after shelf-life.

Potassium bicarbonate treatments exhibited an increase in the SS content after 50 days of cold storage, especially when applied only at preharvest, whereas the other evaluated characteristics did not differ statistically. 
The SS content remained slightly higher during the shelf-life period of preharvest treatments of potassium bicarbonate. On the other hand, no significant differences in TA and SS/TA were observed among treatments at the end of the shelf-life period (Table 4).

At the end of the shelf-life period, the berry color attributes $L^{*}$ and $C^{*}$ presented significant differences among treatments (Table 5). However, these differences were of little importance, since visually, the color of the bunches were very similar and uniform; the differences can be explained by the lower degree of variation observed among treatments and replications, measured by the coefficient of variation (CV). In addition, the color index for red grapes (CIRG), which ranged from 3.9 to 4.9 , did not differ among the treatments (Table 5, Figure 2).

Table 5. Color attributes of luminosity $\left(L^{*}\right)$, chroma $\left(C^{*}\right)$, hue angle $\left(h^{\circ}\right)$ and color index of red grapes (CIRG) of 'BRS Isis' seedless table grapes subjected to preharvest (PreH), pre- and postharvest (PreH/PostH) and postharvest (PostH) treatments, at 50 days after cold storage (50-ACS) and at five days of shelf-life (5-ASL).

\begin{tabular}{ccccccccc}
\hline \multirow{2}{*}{ Treatments $^{\mathbf{z}}$} & \multicolumn{3}{c}{$\mathbf{L}^{*}$} & \multicolumn{2}{c}{$\mathrm{C}^{*}$} & \multicolumn{2}{c}{$\boldsymbol{h}^{\circ}$} & \multicolumn{2}{c}{ CIRG } \\
\cline { 2 - 9 } & 50-ACS & 5-ASL & 50-ACS & 5-ASL & 50-ACS & 5-ASL & 50-ACS & 5-ASL \\
\hline Control & $22.8^{\mathrm{ns} y}$ & $23.9 \mathrm{ab}$ & $4.8^{\mathrm{ns}}$ & $23.9 \mathrm{ab}$ & $57.0 \mathrm{~ns}$ & $55.9^{\mathrm{ns}}$ & $4.5^{\mathrm{ns}}$ & $4.3^{\mathrm{ns}}$ \\
Control + Botrytis & 23.6 & $24.7 \mathrm{a}$ & 5.4 & $24.7 \mathrm{a}$ & 61.7 & 61.4 & 4.1 & 3.9 \\
PreH PB + Botrytis & 22.5 & $22.5 \mathrm{ab}$ & 5.2 & $22.5 \mathrm{ab}$ & 51.0 & 49.3 & 4.6 & 4.9 \\
PreH/PostH PB + Botrytis & 22.6 & $21.9 \mathrm{~b}$ & 4.9 & $21.9 \mathrm{~b}$ & 74.8 & 51.0 & 3.8 & 4.8 \\
PostH PB + Botrytis & 23.5 & $23.4 \mathrm{ab}$ & 5.5 & $23.4 \mathrm{ab}$ & 61.6 & 61.5 & 4.1 & 4.2 \\
PreH Se + Botrytis & 22.5 & $22.0 \mathrm{~b}$ & 4.4 & $22.0 \mathrm{~b}$ & 54.8 & 59.9 & 4.7 & 4.6 \\
PreH/PostH Se + Botrytis & 22.5 & $22.0 \mathrm{~b}$ & 5.3 & $22.0 \mathrm{~b}$ & 59.7 & 64.1 & 4.3 & 4.5 \\
PostH Se + Botrytis & 23.3 & $23.7 \mathrm{ab}$ & 5.7 & $23.7 \mathrm{ab}$ & 57.5 & 65.7 & 4.2 & 4.0 \\
\hline CV (\%) & 3.1 & 4.0 & 15.4 & 4.0 & 12.4 & 11.8 & 8.0 & 9.5 \\
\hline
\end{tabular}

${ }^{\mathrm{z}}$ Treatments: potassium bicarbonate $1 \%(\mathrm{~PB})$ and Serenade ${ }^{\circledR} 3 \mathrm{~L} \mathrm{ha}^{-1}(\mathrm{Se}) .{ }^{\mathrm{y}}$ Means in a column followed by different letters are statistically different according to Scott-Knott's test $(p \leq 0.05)$. ns: differences not significant. CV: coefficient of variation. ACS: days after cold storage; ASL: days after shelf-life.
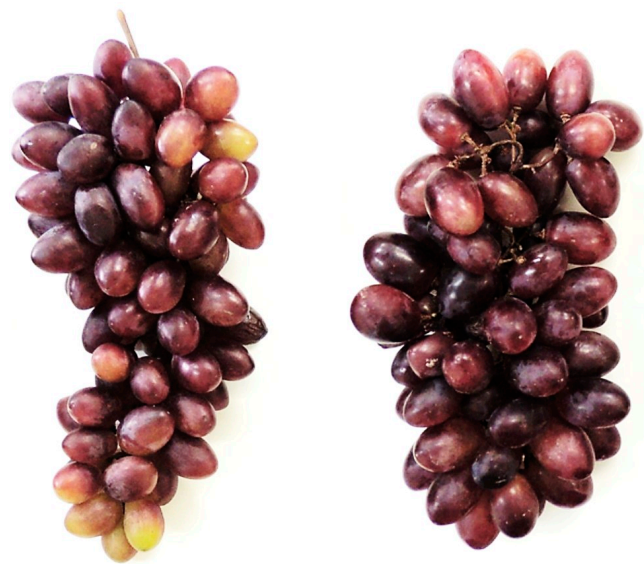

Figure 2. 'BRS Isis' seedless table grape bunches with no gray mold (Botrytis cinerea) symptoms 50 days after cold storage and five days of shelf-life.

\section{Discussion}

Table grape storage and shelf-life maintenance can be limited by factors that cause important economic losses to the grape industry. These include bunch dehydration (berry water loss and stem browning), skin color changes, accelerated softening, and microbiological damage, especially gray mold decay caused by B. cinerea [37]. Therefore, table grapes for export must be resistant to cold storage conditions, without incurring significant losses in its other quality properties. The high-quality 
'BRS Isis' grapes in cold storage can be maintained for over 50 days (Figure 2), which makes this new seedless cultivar very promising for long-distance transportation.

Interestingly, the use of potassium bicarbonate and microbiological agents (Serenade ${ }^{\circledR}$ ) combined with cold storage at pre- or postharvest to control gray mold in 'BRS Isis' seedless grapes, seems to have little effect. In fact, the disease incidence ranged from 2 to $10 \%$ across all treatments and these treatments against gray mold were not effective compared to the non-treated control and Botrytis inoculation, which had $5 \%$ disease incidence on clusters.

For bunches of 'Benitaka' and 'Italia' table grapes inoculated with B. cinerea conidial suspensions, Youssef and Roberto $[18,19]$ reported gray mold incidence values close to 15 and $25 \%$, respectively, after 30 days of cold storage. Moreover, for 'BRS Vitoria' table grapes inoculated under similar conditions, the gray mold incidence observed was higher than $40 \%$ [10]. Thus, the incidence values can change according to cultivar, storage time, temperature, and packing conditions. Nevertheless, these authors achieved gray mold control in table grape cultivars using salt strategies, such as potassium bicarbonate $[18,19]$ and sulfur dioxide releasing pads [10].

Despite the control of gray mold disease that we observed in this study, the bunches treated with potassium bicarbonate and Serenade ${ }^{\circledR}$ at pre- and postharvest, or both, had lower water losses during the cold storage. This is interesting because grapes are sold by weight, thus water loss results in reduced bunch weight, which consequently reduces its price. However, this performance did not extend to the shelf-life period, during which water losses were similar among all the treatments. This can be related to the higher temperatures and lower relative humidity under these conditions, compared to those during cold storage; these conditions are more favorable for water loss.

Compared to their values at harvest, the SS content, TA and SS/TA values for 'BRS Isis' seedless table grapes remained unchanged during cold storage for 50 days. In contrast, grapes treated with potassium bicarbonate at preharvest increased their SS contents after the 50-day cold storage period.

As 'BRS Isis' table grapes have lower TA values compared to other table grape cultivars like 'Benitaka' and 'Italia' $[18,19]$. Tables $2-4$ show that the SS/TA values were within the parameters required by the European Union for the table grape market (higher than 20:1) [38].

In the present study, grape bunches were packaged in carton boxes and plastic liners, which allowed the creation of a modified atmosphere (i.e., one with high relative humidity and low levels of gas exchange), which may have contributed to the reduced losses in quality properties. As a non-climacteric fruit, grapes have a relatively low rate of physiological activity; thus, they are not susceptible to injury at low (but not freezing) temperatures [39]. Therefore, storage at around $0{ }^{\circ} \mathrm{C}$ is recommended for ripe table grapes during postharvest $[1,40,41]$. In general, it has been reported that $\mathrm{SS}, \mathrm{TA}$, and $\mathrm{pH}$ values remained quite constant in different varieties of grapes stored at $0{ }^{\circ} \mathrm{C}$ under several conditions in a controlled atmosphere [42].

Higher relative humidity also contributes to the maintenance of good postharvest table grape quality. For example, prior work has found that relative humidity values between $90 \%$ and $95 \%$ offers the best conditions to maintain the postharvest quality of 'Niagara Rosada' table grapes [43]. However, higher relative humidity is also highly favorable to the development of pathogens that promote berry decay.

The high humidity within table grape packages minimizes water loss, but it can also cause water condensation once the cold chain is broken and the cold fruits are placed in a warm environment. High humidity and free water conditions facilitate conidial germination and penetration through cracks or microlesions that can occur during harvest and subsequent handling. These conditions are ideal for infection because fruit tissues after harvest and during cold storage are less reactive due to the weakening of defense mechanisms [32,44]. However, high humidity can be avoided by placing moisture absorption pads at the bottom of the carton boxes. Even without such pads, 'BRS Isis' grapes performed well during the cold storage and shelf-life periods, demonstrating that they can be stored for over 50 days without significant losses in their physicochemical characteristics, such as SS content, $\mathrm{TA}$, and color attributes. 


\section{Conclusions}

Cold storage at $1{ }^{\circ} \mathrm{C}$ is an efficient postharvest technique to reduce natural gray mold incidence in 'BRS Isis' seedless grape for a period of 50 days. This method controls the disease even when grapes were artificially inoculated, whereas higher water loss was observed in the control treatments.

Application of potassium bicarbonate and Serenade ${ }^{\circledR}$ one week before harvest had no effect on water loss and grape chemical properties at harvest. Potassium bicarbonate applied at preharvest and pre and postharvest led to increased levels of soluble solids (SS); however, titratable acidity (TA) and SS/TA were not influenced by any treatment.

Author Contributions: R.C.C. conceived the idea and conducted literature review, data collection, laboratory analysis, data statistical analysis, and manuscript writing; D.U.C. performed literature review, data collection, laboratory analysis, manuscript writing; M.A.d.C. performed literature review, data collection, laboratory analysis, manuscript writing; C.H.S. performed literature review, data collection, laboratory analysis; S.A. performed literature review, data collection, laboratory analysis; P.A.B. performed data collection, laboratory analysis, manuscript writing; R.T.S. obtained the funding and materials and coordinated the study; S.R.R. obtained the funding and materials, oriented and coordinated the study.

Funding: This research was funded by CNPq-National Council for Scientific and Technological Development, Brazil, grant number 305534/2013-0.

Acknowledgments: The authors are grateful to CNPq, CAPES-Coordination for the Improvement of Higher Education Personnel, and EMBRAPA Grape and Wine for financial and technical support.

Conflicts of Interest: The authors declare no conflict of interest.

\section{References}

1. Rosales, R.; Romero, I.; Fernandez-Caballero, C.; Escribano, M.I.; Merodio, C.; Sanchez-Ballesta, M.T. Low Temperature and Short-Term High $\mathrm{CO}_{2}$ treatment in postharvest storage of table grapes at two maturity stages: Effects on Transcriptome Profiling. Front. Plant Sci. 2016, 7, 1020. [CrossRef] [PubMed]

2. Orak, H.H. Total antioxidant activities, phenolics, anthocyanins, polyphenoloxidase activities of selected red grape cultivars and their correlations. Sci. Hortic. 2007, 111, 235-241. [CrossRef]

3. Rastija, V.; Srecnik, G.; Saric, M.M. Polyphenolic composition of Croatian wines with different geographical origins. Food Chem. 2009, 115, 54-60. [CrossRef]

4. Georgiev, V.; Ananga, A.; Tsolova, V. Recent Advances and Uses of Grape Flavonoids as Nutraceuticals. Nutrients 2014, 6, 391-415. [CrossRef] [PubMed]

5. $\quad$ Ritschel, P.S.; Maia, J.D.G.; Camargo, U.A.; Souza, R.T.; Fajardo, T.V.M.; Naves, R.L.; Girardi, C.L. BRS Isis: Nova Cultivar de Uva de Mesa Vermelha, sem Sementes e Tolerante ao Míldio; Comunicado Técnico 143; Embrapa: Brasilia, Brazil, 2013; pp. 6-11.

6. Ahmed, S.; Roberto, S.R.; Colombo, R.C.; Koyama, R.; Shahab, M.; Souza, R.T. Performance of the new seedless grape 'BRS Isis' grown in subtropical area. BIO Web Conf. 2017, 9, 1-3. [CrossRef]

7. Shin, Y.; Ryu, J.A.; Liu, R.H.; Nock, J.F.; Watkins, C.B. Harvest maturity, storage temperature and relative humidity affect fruit quality, antioxidant contents and activity, and inhibition of cell proliferation of strawberry fruit. Postharvest Biol. Technol. 2008, 49, 201-209. [CrossRef]

8. Genta, W.; Tessmann, D.J.; Roberto, S.R.; Vida, J.B.; Colombo, L.A.; Scapin, C.R.; Ricce, W.S.; Clovis, L.R. Manejo de míldio no cultivo protegido de videira de mesa ‘BRS Clara'. Pesquisa Agropecuária Brasileira 2010, 45, 1388-1395. [CrossRef]

9. Buffara, C.R.S.; Angelotti, F.; Vieira, F.A.; Bogo, A.; Tessmann, D.J.; Bem, B.P. Elaboration and validation of a diagrammatic scale to assess downy mildew severity in grapevine. Ciência Rural 2014, 44, 1384-1391. [CrossRef]

10. Youssef, K.; Roberto, S.R.; Chiarotti, F.; Koyama, R.; Hussain, I.; Souza, R.T. Control of Botrytis mold of the new seedless grape 'BRS Vitoria' during cold storage. Sci. Hortic. 2015, 193, 316-321. [CrossRef]

11. Pearson, R.C.; Goheen, A.C. Compendium of Grape Diseases; APS Press: St. Paul, MN, USA, 1988; 96p.

12. Williamson, B.; Tudzynsk, B.; Tudzynski, P.; van Kan, J.A. Botrytis cinerea: The cause of grey mold disease. Mol. Plant Pathol. 2007, 8, 561-580. [CrossRef] [PubMed] 
13. Feliziani, E.; Smilanick, J.L.; Margosan, D.A.; Mansour, M.F.; Romanazzi, G.; Gu, S.; Gohil, H.L.; Rubio Ames, Z. Preharvest fungicide, potassium sorbate, or chitosan use on quality and storage decay of table grapes. Plant Dis. 2013, 97, 307-314. [CrossRef]

14. Romanazzi, G.; Feliziani, E. Botrytis cinerea (Gray mold). In Postharvest Decay: Control Strategies; Bautista-Baños, S., Ed.; Elsevier: London, UK, 2014; pp. 131-146. ISBN 9780124115521.

15. Smilanick, J.L.; Mansour, M.F.; Gabler, F.M.; Margosan, D.A.; Hashim-Buckey, J. Control of postharvest gray mold of table grapes in the San Joaquin Valley of California by fungicides applied during the growing season. Plant Dis. 2010, 94, 250-257. [CrossRef]

16. Ippolito, A.; Sanzani, S.M. Control of postharvest decay by the integration of pre- and postharvest application of nonchemical compounds. Acta Hortic. 2011, 905, 135-143. [CrossRef]

17. Youssef, K.; Ligorio, A.; Nigro, F.; Ippolito, A. Activity of salts incorporated in wax in controlling postharvest diseases of citrus fruit. Postharvest Biol. Technol. 2012, 65, 39-43. [CrossRef]

18. Youssef, K.; Roberto, S.R. Salt strategies to control Botrytis mold of 'Benitaka' table grapes and to maintain fruit quality during storage. Postharvest Biol. Technol. 2014, 95, 95-102. [CrossRef]

19. Youssef, K.; Roberto, S.R. Applications of salt solutions before and after harvest affect the quality and incidence of postharvest gray mold of 'Italia' table grapes. Postharvest Biol. Technol. 2014, 87, 95-102. [CrossRef]

20. Palou, L.; Crisosto, C.H.; Garner, D.; Basinal, L.M.; Smilanick, J.L.; Zoffoli, J.P. Minimum constant sulfur dioxide emission rates to control gray mold of cold stored table grapes. Am. J. Enol. Vitic. 2002, 52, 110-115.

21. Fernández-Trujillo, J.P.; Obando-Ulloa, J.M.; Baró, R.; Martínez, J.A. Quality of two table grape guard cultivars treated with single or dual-phase release $\mathrm{SO}_{2}$ generators. J. Appl. Bot. Food Qual. 2008, 82, 1-8.

22. Lichter, A.; Zutahy, Y.; Kaplunov, T.; Lurie, S. Evaluation of table grape storage in boxes with sulfur dioxide-releasing pads with either an internal plastic liner or external wrap. HortTechnology 2008, 18, $206-214$.

23. Zutahy, Y.; Lichter, A.; Kaplunov, T.; Lurie, S. Extended storage of 'Red Globe' grapes in modified $\mathrm{SO}_{2}$ generating pads. Postharvest Biol. Technol. 2008, 50, 12-17. [CrossRef]

24. Furtado, L.M.; Rodrigues, A.A.C.; Araújo, V.S.; Silva, L.L.S.; Catarino, A.M. Utilização de Ecolife ${ }^{\circledR}$ e Acibenzolar-s-metil (ASM) no controle da antracnose da banana em pós-colheita. Summa Phytopathol. 2010, 36, 237-239. [CrossRef]

25. Zhu, X.; Lin, H.; Si, Z.; Xia, Y.; Chen, W.; Li, X. Benzothiadiazole-Mediated Induced Resistance to Colletotrichum musae and Delayed Ripening of Harvested Banana Fruit. J. Agric. Food Chem. 2016, 64, 1494-1502. [CrossRef] [PubMed]

26. Mazaro, S.M.; Deschamps, C.; Mio, L.L.M.; Biasi, L.A.; Gouvea, A.; Sautter, C.K. Comportamento pós-colheita de frutos de morangueiro após a aplicação pré-colheita de quitosana e Acibenzolar-s-metil. Rev. Bras. Frutic. 2008, 30, 185-190. [CrossRef]

27. Romanazzi, G.; Feliziani, E.; Santini, M.; Landi, L. Effectiveness of postharvest treatment with chitosan and other resistance inducers in the control of storage decay of strawberry. Postharvest Biol. Technol. 2013, 75, 24-27. [CrossRef]

28. Liu, Y.; Geb, Y.; Bia, Y.; Li, C.; Deng, H.; Dong, B. Effect of postharvest acibenzolar-S-methyl dipping on phenylpropanoid pathway metabolism in muskmelon (Cucumis melo L.) fruits. Sci. Hortic. 2014, 168, 113-119. [CrossRef]

29. Panebianco, S.; Vitale, A.; Platania, C.; Restuccia, C.; Polizzi, G.; Cirvilleri, G. Postharvest efficacy of resistance inducers for the control of green mold on important Sicilian citrus varieties. J. Plant Dis. Prot. 2014, 121, 177-183. [CrossRef]

30. Oliveira, E.S.; Viana, F.M.P.; Martins, M.V.V. Alternativas a Fungicidas Sintéticos no Controle da Antracnose da Banana. Summa Phytopathol. 2016, 42, 340-350. [CrossRef]

31. Ribeiro, J.G.; Serra, I.M.R.S.; Araújo, M.U.P. Uso de produtos naturais no controle de antracnose causado por Colletotrichum gloeosporioides em mamão. Summa Phytopathol. 2016, 42, 160-164. [CrossRef]

32. Romanazzi, G.; Smilanick, J.L.; Feliziani, E.; Droby, S. Integrated management of postharvest gray mold on fruit crops. Postharvest Biol. Technol. 2016, 113, 69-76. [CrossRef]

33. Paul, N.C.; Deng, J.X.; Lee, H.B.; Yu, S.-H. Characterization and pathogenicity of Alternaria burnsii from seeds of Cucurbita maxima (Cucurbitaceae) in Bangladesh. Mycology 2015, 43, 384-391. [CrossRef] [PubMed]

34. Mattiuz, B.; Miguel, A.C.A.; Galati, V.C.; Nachtigal, J.C. Efeito da temperatura no armazenamento de uvas apirênicas minimamente processadas. Rev. Bras. Frutic. 2009, 31, 44-52. [CrossRef] 
35. Carreño, J.; Martínez, A.; Almela, L.; Fernández-López, J.A. Proposal of an index for the objective evaluation of the color of red table grapes. Food Res. Int. 1995, 28, 373-377. [CrossRef]

36. Roberto, S.R.; Borges, W.F.S.; Colombo, R.C.; Koyama, R.; Hussain, I.; Souza, R.T. Berry-cluster thinning to prevent bunch compactness of 'BRS Vitoria', a new black seedless grape. Sci. Hortic. 2015, 197, 297-303. [CrossRef]

37. Palou, L.; Serrano, M.; Martinez-Romero, D.; Valero, D. New approaches for postharvest quality retention of table grapes. Fresh Prod. 2010, 4, 103-110.

38. UNECE. Standard FFV-19 Concerning the Marketing and Commercial Quality Control of Table Grapes. 2010. Available online: https:/ / www.unece.org/fileadmin/DAM/trade/agr/standard/fresh/FFV-Std/English/ 19TableGrapes.pdf (accessed on 22 June 2018).

39. Creasy, G.L.; Creasy, L.L. Grapes. Crop Production Science in Horticulture; CABI: Cambridge, MA, USA, 2009; 312p.

40. Romero, I.; Sanchez-Ballesta, M.T.; Maldonado, R.; Escribano, M.I.; Merodio, C. Expression of a class I chitinase and $\beta$-1,3-glucanase genes and postharvest fungal decay control of table grapes by high $\mathrm{CO}_{2}$ pretreatment. Postharvest Biol. Technol. 2006, 41, 9-15. [CrossRef]

41. Sanchez-Ballesta, M.T.; Jiménez, J.B.; Romero, I.; Orea, J.M.; Maldonado, R.; Ureña, A.G.; Escribano, I.; Merodio, C. Effect of high $\mathrm{CO}_{2}$ pretreatment on quality, fungal decay and molecular regulation of stilbene phytoalexin biosynthesis in stored table grapes. Postharvest Biol. Technol. 2006, 42, 209-216. [CrossRef]

42. Artés-Hernández, F.; Tomàs-Barberán, F.A.; Artés, F. Modified atmosphere packaging preserves quality of $\mathrm{SO}_{2}$-free 'Superior seedless' table grapes. Postharvest Biol. Technol. 2006, 39, 146-154. [CrossRef]

43. Pinto, J.A.V.; Schorr, M.R.W.; Thewes, F.R.; Ceconi, D.L.; Both, V.; Auri, B.; Diniz, F. Relative humidity during cold storage on Postharvest quality of 'Niagara Rosada' table grapes. Ciência Rural 2015, 45, 386-391. [CrossRef]

44. Coertze, S.; Holz, G. Surface colonization, penetration, and lesion formation on grapes inoculated fresh or after cold storage with single airborne conidia of Botrytis cinerea. Plant Dis. 1999, 83, 917-924. [CrossRef]

(c) 2018 by the authors. Licensee MDPI, Basel, Switzerland. This article is an open access article distributed under the terms and conditions of the Creative Commons Attribution (CC BY) license (http:/ / creativecommons.org/licenses/by/4.0/). 